ISSN: 2146-3042

DOI:

\title{
Beneish Modelinin Türkiye'ye Uyarlanması: Tespit Başarımını Geliştiren Bir Uygulama*
}

\author{
Serdar BENLİGIRAY** \\ Ahmet ONAY***
}

\begin{abstract}
$\ddot{O Z Z T}$
Finansal bilgi manipülasyonuna başvurarak kazançlarını olduğundan farklı gösteren şirketleri saptamak için kullanılan araçlar arasında Beneish Modeli öne çıkmaktadır. Bir dizi araş̧ırmada manipülatör şirketleri sınıflandırmak için modelin geliştirildiği esas çalışmada raporlanan katsayılar ve kesim noktası kullanılmıştır. Modelin sınıflandırma başarımında modelin bileşenleri kadar bileşenlerin model içindeki ağırlıkları da önem taşır. Bu bağlamda, Türkiye'deki şirketlerde uygulanan manipülasyonları tahmin etmek için kullanılacak ideal model katsayıları, yabancı bir ülkedeki şirketlerin geçmişte bir döneme ait verisiyle türetilmiş katsayllardan farkllık gösterebilir. Bu görüşten hareketle, Beneish Modeli Türkiye'deki şirketlere ait güncel veriyle probit regresyon yöntemi kullanılarak yeniden çalıştırlmış ve böylece Türkiye'ye uygun güncel model katsaylları elde edilmiştir. Sonrasında, elde edilen model ile orijinal modelin Türkiye'deki düzenleyici ve denetleyici otorite tarafindan önceden saptanmış olan manipülasyonları tahmin etmedeki başarımları ölçülmüş̧ür. 2013-2019 dönemi verisinin kullanıldığ karşılaştırmada, bu çalışmada türetilen probit modelinin Türkiye'deki manipülatör şirketlerin tespitinde orijinal Beneish Modelinden daha başarılı olduğu gözlenmiştir. Sonuçta, orijinal modele bir alternatif önerilmiş ve sınıflandırma için uygun kesim noktası ile birlikte sunulmuştur.
\end{abstract}

Anahtar Kelimeler: Kazanç Manipülasyonu, Beneish M Skoru, Finansal Bilgi Manipülasyonu, Probit Modeli.

JEL Sinıflandırması: D82, G17, M41, K42

\section{Fine-Tuning the Beneish Model for Turkey: An Application that Improves the} Detection Performance

\section{ABSTRACT}

Beneish Model stands out among the tools used to detect companies that misrepresent their earnings by manipulation of financial information. A number of studies utilizing the classification of manipulators used the coefficients and the cut-off point reported in the primary study in which the model was developed. For the classification performance of the model, the weights of the components are important just as the model composition. In this context, the ideal model coefficients to predict manipulations practiced by the companies in Turkey may differ from the coefficients derived from data of foreign companies for a period in the past. Beneish Model is rerun with contemporaneous data of the companies in Turkey by using the probit regression method and the model coefficients are obtained which are up to date and applicable to Turkey. Thereafter, the obtained model and the original model are measured for their performance of prediction of the pre-detect manipulations by the regulatory and supervisory authority in Turkey. In the comparison using 2013-2019 period data, it is observed that the obtained model performs better than the original Beneish model in terms of detecting manipulator companies in Turkey. Consequently, an alternative to the Beneish Model is proposed and provided with an appropriate cutting point for the classification.

Keywords: Earnings Manupilation, Beneish M Score, Manupilations of Financial Information, Probit Model.

Jel Classification: D82, G17, M41, K42

* Bu makale, 23-25 Nisan 2021 tarihleri arasında gerçekleştirilen VI. Uluslararası Muhasebe ve Finans Sempozyumunda bildiri olarak sunulmuştur.

Makale Gönderim Tarihi: 04.06.2021, Makale Kabul Tarihi: 20.06.2021, Makale Türü: Nicel Araştırma ** Dr. Öğr. Üyesi, Anadolu Üniversitesi, serdarbenligiray@anadolu.edu.tr, ORCID: 0000-0001-7593-7971.

*** Dr. Öğr. Üyesi, Eskişehir Teknik Üniversitesi, ahmet_onay@eskisehir.edu.tr, ORCID: 0000-0003-11826003. 


\section{GíRiş}

Sanayi Devrimi sonrasında sermaye birikimi ve finansal imkânların gelişmesi, büyük ölçekli halka açık şirketlerin sayısının giderek artmasına yol açmıştır. Halka açık şirketlerde sahipliğin ve kontrolün birbirinden ayrılmasının doğal bir sonucu olarak, hissedarlar ile yöneticiler arasında bir vekâlet sorunu ortaya çıkmıştır. Bu sorunun temelinde şirkete ait tüm bilgiye erişimi olan yöneticiler ile yöneticilerin eylemleri üzerinde sınırlı bir gözetim gücüne sahip olan hissedarlar arasındaki bilgi asimetrisi yer alır. Bu koşullar altında yöneticilerin her zaman vekili oldukları hissedarların çıkarlarına -özellikle hissedarlar ile aralarında çıkar çatışması olduğu durumda- uygun eylemlerde bulunmaması, insan doğasının öngörülebilir bir sonucudur. Bu bağlamda yöneticiler, şirketlerin paydaşları ile arasındaki en önemli iletişim araçlarından biri olan finansal raporlamayı kendi amaçları doğrultusunda yönlendirebilirler. Tahakkuk esaslı muhasebenin doğasından kaynaklanan finansal raporlama üzerindeki takdir yetkisinin, Genel Kabul Görmüş Muhasebe İlkeleri'nin (GKGMI) kapsamı içerisinde kullanılması beklenir. Fakat bazı durumlarda yönetimin takdir yetkisi, kötü niyetin boyutları ile tutarlı olarak GKGMİ'nin sınırlarının ötesine geçer ve meşruiyetini tartışmasız bir şekilde kaybeder. Söz konusu ikinci durum, kazanç manipülasyonu bağlamında değerlendirilir.

2000'li yıllarda yaşanan muhasebe skandalları, uygulamacıları ve araştırmacıları finansal bilgi manipülasyonunun tespitine yönelik çalışmalara yönlendirmiştir. Birçok çalışmada, finansal tablo verilerini kullanarak finansal bilgi manipülasyonuna işaret etmesi beklenen ilişkileri ve kalıpları ortaya çıkarmaya çalışan analitik modeller ele alınmıştır. Kazanç manipülasyonu açısından M. Daniel Beneish tarafından geliştirilen model, bunlar arasından popülerliği, uygulanabilirliği ve güvenilirliğiyle öne çıkmıştır. Beneish'in modeli şirketin kazanç manipülatörü olma olasılığını yansıtan bir değer sunar ve çok sayıda farklı şirketin karşılaştırılmasına imkân tanır. Beneish Modeli'nin kazanç manipülasyonunu tespit etmek için etkili ve güçlü bir araç olduğu, farklı ülkelerde yürütülen birçok farklı çalışma ile doğrulanmıştır.

Bu çalışmada, kazanç manipülasyonlarını tespit etmek için geliştirilen Beneish modeli ve bir türevinin, Türk şirketlerine ait güncel veri üzerinde test edilerek, model katsayılarının Türkiye'ye uyarlanması amaçlanmıştır. Bunun için Beneish modelinde yer alan değişkenlerin Türkiye'deki şirketlerin kazanç manipülasyonu eylemlerini açıklamadaki etkisi probit regresyon modeliyle test edilmiştir. Böylece Türkiye'deki şirketlerin manipülatif eylemlerinin hangi finansal tablo kalemleriyle ilişkili olabileceği konusunda bir yargıya varılabilecektir. Ayrıca, bu çalışmada elde edilen probit modeli sonuçları, Beneish modeli ve türevleriyle Türkiye'deki şirketlerin finansal verilerini inceleyen benzer çalışmaların sonuçlarıyla karşılaştırılmıştır. Araştırmanın sonuçları, Türkiye'deki kazanç manipülasyonu uygulamalarının saptanmasında kullanılan modellerin tespit başarımını göstermesi ve uyarlanan katsayılarla başarımın artırılması bakımından önem taşımaktadır.

Çalışmanın bundan sonraki bölümünde Beneish modeli ve bu modelin yansıra Türkiye'deki şirketlerin kazanç manipülasyonu eylemlerini tespit etmek için Beneish'in modelini temel alarak geliştirilen Küçüksözen'in modeli tanıtılmıştır. Ek olarak, Türkçe literatürde bu modelleri yeniden çalıştırarak regresyon çıktısı raporlayan çalışmalar incelenmiştir. Çalışmanın analiz bölümünde, Türkiye'deki şirketlerin finansal verileri üzerinde kazanç manipülasyonunu açıklayan probit regresyon modeli test edilmiş ve benzer çalışmaların sonuçlarıyla karşılaştırılmıştır. Son bölümde analizden çıkarılan sonuçlar 
yorumlanmıştır. Çalışmanın sonucunda, Beneish modeli için Türkiye'ye özgü model katsayıları önerilmiştir.

\section{LITERATÜR}

Beneish (1999) çalışmasında elde edilen M skoru modelinin temeli Beneish'in (1997) çalışmasına dayanır. Beneish (1997) çalışmasında, GKGMİ'yi ihlal eden 64 şirketi incelemiştir. Bu şirketler, ABD'deki denetleyici otorite (Securities Exchange Commission, SEC) tarafından muhasebe ve denetim uygulama tebliğlerine aykırı şekilde GKGMİ'yi ihlal ettiği tespit edilen 49 şirket ile kesin bir şekilde GKGMİ'yi ihlal ettiği kamuoyuna yansıyan 15 şirketten oluşmaktadır. Bu çalışmada kontrol örneklemi, yüksek seviyede pozitif ihtiyari tahakkukları olduğu için kazancını agresif şekilde yönettiği düşünülen şirketlerden oluşturulmuştur. Çünkü Beneish'in bu araştırmadaki amacı, GKGMİyi ihlal eden kazanç manipülatörü şirketleri, kazancını agresif de olsa meşru sınırlar içinde yöneten şirketlerden ayırmaktır ${ }^{1}$. Beneish (1997) çalışmasında, finansal tablo değişkenlerinin yanı sıra sahiplik yapısı, halka açılma zamanı, geçmiş piyasa performansı ve bağımsı denetim gibi değişkenlere de yer vermiştir. Çalışmada, kazancını agresif şekilde yöneten şirketler arasında GKGMI'yi ihlal ederek kazancını manipüle eden şirketlerin ihlal yılında daha düşük tahakkuklar raporladığı, daha düşük borsa performansına sahip olduğu ve daha fazla finansal kaldıraç kullandığı tespit edilmiştir.

Beneish (1999) çalışmasında, 1997 yılındaki çalışmasını geliştirmeyi amaçlamıştır. Bu çalışmanın sonucunda tamamen finansal tablo değişkenlerine dayalı bir kazanç manipülasyonu tespit modeli olan M-skoru modeline ulaşılmıştır. GKGMİ'yi ihlal eden 74 şirketi ve daha genel bir yapıdaki kontrol örneklemini içeren Beneish'in (1999) kullandığı veri seti ve modellenen değişkenler 1997'deki çalışmasından farklıdır. Çalışmada elde edilen Mskoru modeli, bir şirketin kazanç manipülatörü olma olasılığını etkileyen motivasyonlar ve bu olasılığa işaret eden göstergeler üzerinden kurgulanan bir kazanç manipülasyonu tespit aracıdır. Model, kazanç manipülasyonundan kaynaklanma potansiyeline sahip olan anormallikleri tespit etmek için yapılandırılmış sekiz finansal tablo tabanlı değişkenden oluşur. Bu çalışmada, manipülatör şirketlerin ortalamalara göre daha küçük, daha az kar eden, daha fazla borç yüküne sahip ve sektör ortalamalarına göre daha hızlı büyüyen şirketler olduğu belirlenmiştir.

Beneish, finansal raporlardan elde edilen değişkenler aracılığıyla kazanç manipülasyonu olasılığını hesaplamak için probit regresyon modeli kullanmıştır: $M_{i}=\beta \mathrm{X}_{\mathrm{i}}+$ $\epsilon_{\mathrm{i}}$. Bu denklemde $M_{i}$, dikotom bağımsız değişkeni; $\mathrm{X}_{\mathrm{i}}$, bağımsız değişkenlerin oluşturduğu matrisi; $\epsilon_{\mathrm{i}}$, hata terimini ifade eder. Modelde yer alan finansal tablo tabanlı değişkenler ve hesaplamaları aşağıda sunulmuştur:

$$
\begin{aligned}
& \text { Alacaklar Endeksi (DSRI) }=\frac{\text { Alacaklar }_{\mathrm{t}} / \text { Satıșlar }_{\mathrm{t}}}{\text { Alacaklar }_{\mathrm{t}-1} / \text { Satıșlar }_{\mathrm{t}-1}} \\
& \text { Brüt Kâr Marj1 Endeksi (GMI) }=\frac{\left(\text { Satıșlar }_{\mathrm{t}-1}-\text { Satılan Malın Maliyeti }_{\mathrm{t}-1}\right) / \text { Satışlar }_{\mathrm{t}-1}}{\left(\text { Satışlar }_{\mathrm{t}}-\text { Satılan Malın Maliyeti }_{\mathrm{t}}\right) / \text { Satıșlar }_{\mathrm{t}}}
\end{aligned}
$$

\footnotetext{
${ }^{1}$ Kazanç yönetimi ile kazanç manipülasyonu ayrımı için bu kavramları finansal bilgi manipülasyonu bağlamında tartışan Benligiray ve Onay'ın (2020) çalışması incelenebilir.
} 
Varlık Kalitesi Endeksi (AQI)

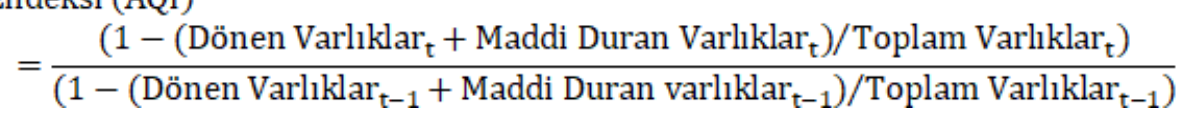

Satışlardaki Büyüme Endeksi (SGI) $=\frac{\text { Satıșlar }_{\mathrm{t}}}{\text { Satıșlar }_{\mathrm{t}-1}}$

Amortisman Endeksi (DEPI) $=\frac{\text { Amortisman }_{\mathrm{t}-1} /\left(\text { Amortisman }_{\mathrm{t}-1}+\text { Maddi Duran Varlıklar }_{\mathrm{t}-1}\right)}{\text { Amortisman }_{\mathrm{t}} /\left(\text { Amortisman }_{\mathrm{t}}+\text { Maddi Duran Varlıklar }_{\mathrm{t}}\right)}$

Satıș ve Genel Yönetim Giderleri Endeksi (SGAI) $=\frac{\text { Satıș ve Genel Yönetim Giderleri } t / \text { Satıșlar }_{t}}{\text { Satıș ve Genel Yönetim Giderleri }}$

Kaldıraç Endeksi (LVGI) $=\frac{\left(\text { Uzun Vadeli Borçlar }_{\mathrm{t}}+\text { Kısa Vadeli Yükümlülükler }_{\mathrm{t}}\right) / \text { Toplam Varlıklar }_{\mathrm{t}}}{\left(\text { Uzun Vadeli Borçlar }_{\mathrm{t}-1}+\text { Kısa Vadeli Yükümlülükler }_{\mathrm{t}-1}\right) / \text { Toplam Varlıklar }_{\mathrm{t}-1}}$

Toplam Tahakkukların Toplam Varlıklara Oramı (TATA)

$\Delta$ Dönen Varlıklar ${ }_{\mathrm{t}}-\Delta \mathrm{Kasa}_{\mathrm{t}}-\left(\Delta \mathrm{K}_{1}\right.$ sa Vadeli Yükümlülükler $\mathrm{r}_{\mathrm{t}}$

$=\frac{\left.-\Delta \text { Uzun Vadeli Borçların Kısa Vadeli Kısımları }_{\mathrm{t}}-\Delta \text { Ödenecek Vergiler }_{\mathrm{t}}-\Delta \text { Amortisman Giderleri }_{\mathrm{t}}\right)}{\text { Toplam Varlıklar }_{\mathrm{t}}}$

Beneish vd. (2013), sekiz değişkenin tek tek önemli olmadığını, ancak toplu olarak potansiyel bir kazanç manipülatörünün profilini ortaya koyduğunu vurgulamışlardır. $\mathrm{Bu}$ değişkenlerin her birinde pozitif değerler kazanç manipülasyonu olasılığını yükseltecek şekilde kurgulanmıştır. Değişkenlerin modele dahil edilme gerekçeleri sırasıyla şöyle açıklanmıştır: DSRI, satışların artışından kaynaklanabilecek alacaklardaki tutarsızlıkları tespit eder; GMI, şirketleri kazancı manipüle etmeye iten kar marjındaki azalmayı tespit eder; AQI, bazı giderlerin gelir tablosuna yansitılmayarak fizikî olmayan varlıklarda aktifleştirilmesiyle oluşan varlık kalitesindeki bozulmayı tespit eder; SGI, satışlardaki büyümeyi ölçer; DEPI, bir kazanç manipülasyonu yöntemi olan amortisman tutarlarındaki azalmayı tespit eder; SGAI, yönetim ve pazarlama giderlerindeki verimsizliği tespit eder; LVGI, şirketleri kazançlarını manipüle etmeye itme potansiyeli olan borç yapısındaki değişimi ölçer; TATA, muhasebe kârının nakit akışı ile tutarlı olmadığı durumları tespit eder.

Beneish (1999), manipülasyonu tespit etmek için kurguladığı değişkenlerin katsayılarını ağırlıklandırılmamış probit analizi ile hesaplamıştır. Böylece, şirketlerin kazanç manipülasyonu açısından sınıflandırılmasında kullanılabilecek bir $\mathrm{M}$ skoru formülüne ulaşılmıştır.

$$
\begin{aligned}
& M_{i}=-4,840+0,920 \times \mathrm{DSRI}+0,528 \times \mathrm{GMI}+0,404 \times \mathrm{AQI}+0,892 \times \mathrm{SGI}+0,115 \\
& \quad \times \mathrm{DEPI} \\
& -0,172 \times \mathrm{SGAI}-0,327 \times \mathrm{LVGI}+4,679 \times \text { TATA }
\end{aligned}
$$

Beneish'in model çalışması, yayımlandı̆̆ı yıldan bu yana çok sayıda çalışmanın temelini oluşturmuştur. Uluslararası literatürdeki birçok çalışmada, şirket-yıl verilerini kazanç manipülasyonu bağlamında sınıflandırmak veya finansal bilgi manipülasyonunu tespit etmek amacını taşıyan modeller geliştirmek için Beneish'in modelinden yararlanılmıştır. Araştırmacıların Beneish modeline ilgisinin güncel çalışmalarda da sürdüğü görülmektedir. Son yıllarda yapılan birçok çalışmada, şirketlerin kazanç manipülasyonu açısından 
sınıflandırılması veya karşılaştırılması için Beneish'in modeli kullanılmıştır. Comporek (2020) çalışmasında, Beneish modelinin etkinliğini, 2006-2018 yılları arasında finansal tablolarında Uluslararası Muhasebe/Finansal Raporlama Standartlarına aykırılık tespit edildiği için yaptırım uygulanan Varşova Borsası'na kayıtlı 27 şirketin finansal tablo verisi üzerinde sınamıştır. Holda (2020), benzer sinamayı kamu otoritesinin yaptırımları doğrultusunda 4'ü manipülatör ve 4'ü manipülatör olmayan olarak sinıflandırılan 8 şirket-yıl verisi üzerinde tekrarlamıştır. Fedorko ve Valaskova (2021), taşımacılık sektöründe faaliyet gösteren 135'i Çek ve 68'i Slovak şirketinden oluşturdukları bir örneklem üzerinde her iki ülke şirketlerini kazanç manipülasyonu olasılığı bağlamında Beneish M-skoru ile karşılaştırmışlardır.

Son yıllarda yapılan bazı çalışmalarda ise, Beneish modeli tespit başarımı açısından daha önce geliştirilen türevi modeller ile karşılaştırılmıştır. Svabova (2021), Beneish modeli ile Slovakya şirketleri için geliştirilen Beneish türevi bir modeli kazanç manipülasyonunun tespit başarımı açısından Slovak şirketlerinden oluşan bir örneklem üzerinde karşılaştırmıştır. Vetoshkina vd. (2021) ise, Beneish modeli ile türevi bir modelin tespit başarımı karşılaştırmasını, 15 Rus şirketinin finansal verileri ile gerçekleştirmişlerdir. Bu çalışmalardan farklı olarak Svabova vd. (2020), kazanç manipülasyonunun tespiti için yeni bir Beneish türevi model geliştirmişlerdir. Çalışmalarında, yeni model ile Beneish modelinin başarımının karşılaştırılması, 44 şirketin finansal tablo verisinden oluşan bir örneklem üzerinde gerçekleştirilmiştir. Bazı çalışmalarda ise (Akra ve Chaya, 2020; Jolly ve Chandani, 2020; Kukreja vd., 2020), Altman'nın finansal stres altındaki şirketlerin tespiti için tasarladığı modeli, finansal bilgi manipülasyonunun tespiti için Beneish modeli ile birlikte kullanılmıştır.

Türkçe literatürde Beneish (1999) modelini kullanan öncü çalışma Küçüksözen (2004) tarafından yapılmıştır. Küçüksözen (2004) çalışmasında, Türkiye'deki şirketlerin finansal tablo verilerini analiz etmek için Beneish (1999) modelini revize etmiştir. Küçüksözen (2004), Beneish (1999) modelindeki değişkenlerin yedisini modelinde tutmuş, Satışlardaki Büyüme Endeksi'ni (SGI) modeline dahil etmemiş, bunun yerine iki yeni değişken olarak kurguladığı Stokların Brüt Satışlara Oranı'nı (SSE) ve Finansman Giderlerinin Brüt Satışlara Oranı'nı (FSE) modeline eklemiştir. Satışlardaki nominal değişimi gösteren SGI değişkenine modelde yer verilmemesi, modelin geliştirildiği dönemde Türkiye'de yaşanan yüksek enflasyonun satışlardaki reel değişimi gölgeleyecek düzeyde olmasıyla açıklanmıştır. SSE ve FSE'nin modele eklenmesine ise, Türkiye'deki şirketlerin stoklar ve finansman giderleri hesaplarını kullanarak manipülatif eylemlerde bulunduğu gerekçe gösterilmiştir. Dolayısıyla, bu iki yeni değişkendeki olağandışı değişim ile finansal manipülasyon arasında pozitif ilişki beklenmiştir (Küçüksözen, 2004: 301; Küçüksözen ve Küçükkocaoğlu, 2004: 38). Türkiye özelinde revize edilmiş böyle bir modelin gerekliliğine, Onay ve Benligiray'ın (2021) finansal bilgi manipülasyonları bağlamında Türkiye'deki şirketlerde alacaklar, stoklar ve amortisman giderleri kullanılarak kazancın olduğundan farklı gösterildiğini raporlayan çalışması örnek gösterilebilir.

Küçüksözen (2004) çalışmasında, metodoloji olarak Beneish'i (1999) izleyerek probit analiz uygulamış ve şirketlerin kazanç manipülasyonu açısından sınıflandırılmasını sağlayacak bir M skoru formülüne ulaşmıştır. Küçüksözen'in (2004) modelinde yer alan değişkenlerin formülasyonu ve analiz sonucunda elde edilen $M$ skoru formülü aşağıda sunulmuştur. Küçüksözen (2004) modelinde, Beneish'in (1999) modelinden uyarladığ1 
değişkenlerin formülasyonunda modelin tespit başarımını etkileyebilecek farklılıklar bulunmaktadır.

$$
\begin{aligned}
& \text { Ticari Alacaklar Endeksi (TAE) }=\frac{\text { Ticari Alacaklar }_{\mathrm{t}} / \text { Brüt Satıșlar }_{\mathrm{t}}}{\text { Ticari Alacaklar }_{\mathrm{t}-1} / \text { Brüt Satıșlar }_{\mathrm{t}-1}} \\
& \text { Brüt Kâr Marjı Endeksi }(B K M)=\frac{\left(\text { Brüt Satıșlar }_{\mathrm{t}-1}-\text { Satılan Malın Maliyeti }_{\mathrm{t}-1}\right) / \text { Brüt Satıșlar }_{\mathrm{t}-1}}{\left(\text { Brüt Satıșlar }_{\mathrm{t}}-\text { Satılan Malın Maliyeti }_{\mathrm{t}}\right) / \text { Brüt Satıșlar }_{\mathrm{t}}}
\end{aligned}
$$

Aktif Kalitesi Endeksi ${ }^{2}$ (AKE)

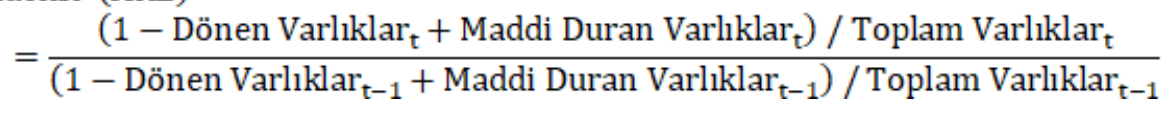

Amortisman Endeksi (AME)

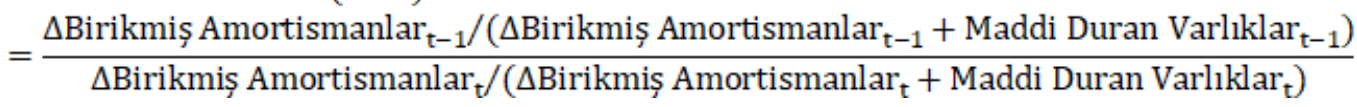

Pazarlama, Satış, Dağıtım ve Genel Yőnetim Giderleri Endeksi (PSE)

$$
=\frac{\left(\text { Pazarlama Satıș Dağıtım Giderleri }_{\mathrm{t}}+\text { Genel Yönetim Giderleri }_{\mathrm{t}}\right) / \text { Brüt Satıșlar }_{\mathrm{t}}}{\left(\text { Pazarlama Satıș Dağıtım Giderleri }_{\mathrm{t}-1}+\text { Genel Yönetim Giderleri }_{\mathrm{t}-1}\right) / \text { Brüt Satıșlar }_{\mathrm{t}-1}}
$$

Borçlanma Yapısındaki Değişim Endekesi (BYE)

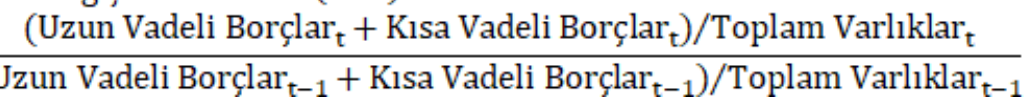

Toplam Tahakkukların Toplam Varlıklara Oranı (TVE)

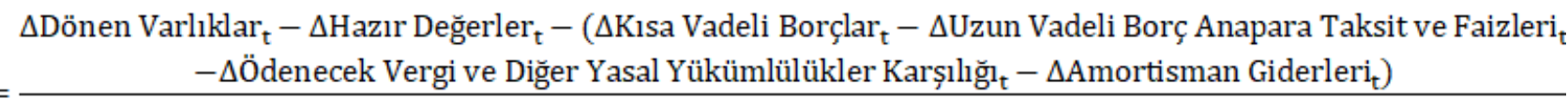

$$
=\frac{\text { Toplam Varliklar }_{\mathrm{t}}}{\mathrm{A}}
$$

Stokların Brüt Satıșlara Oranı (SSE) $=\frac{\text { Stoklar }_{\mathrm{t}} / \text { Brüt Satıșlar }_{\mathrm{t}}}{\text { Stoklar }_{\mathrm{t}-1} / \text { Brüt Satıșlar }_{\mathrm{t}-1}}$

Finansman Giderlerinin Brüt Satıșlara Oranı $(\mathrm{FSE})=\frac{\text { Finansman Giderleri }_{\mathrm{t}} / \text { Brüt Satıșlar }_{\mathrm{t}}}{\text { Finansman Giderleri }_{\mathrm{t}-1} / \text { Brüt Satıșlar }_{\mathrm{t}-1}}$

$$
\begin{aligned}
M_{i}=-1,547 & +1,276 \times \mathrm{TAE}-1,770 \times \mathrm{BKM}+0,082 \times \mathrm{AKE}+0,225 \times \mathrm{AME}-0,488 \\
& \times \mathrm{PSE}
\end{aligned}
$$

\section{$-0,341 \times$ BYE $-0,514 \times$ TVE $+0,972 \times$ SSE $+0,060 \times$ FSE}

Türkçe literatürde birçok çalışma, Türkiye'deki şirketlerin finansal tablo verilerini kazanç manipülasyonu bağlamında analiz etmek için Beneish (1999) ve Küçüksözen (2004) çalışmalarında geliştirilen modellerden yararlanmıştır. Bu çalışmaların önemli bir bölümü

\footnotetext{
${ }^{2} \mathrm{Bu}$ değişkenin dönen varlıklar ve maddi duran varlıklar dışındaki bilanço aktiflerinde meydana gelen değişimi ölçmesi beklenmektedir. Böyle bir ölçümün pay ve paydadaki ifadesi, Beneish (1999) modelindeki AQI değişkenindeki gibi dönen varlıklar ve maddi duran varlıkların toplamının toplam varlıklara oranının 1 rakamından çıkarılmasıdır. Buna karşılık, AKE değişkeninin pay ve paydasında, maddi duran varlıklar ile dönen varlıkların farkı toplan varlıklara oranlanmaktadır. İlgili çalışmada raporlanan AKE değişkeni, özgün çalışmadaki AQI degişkeninden farklı bir ölçümdür.
} 
(Bekçi ve Avşargil, 2011; Varıcı ve Er, 2013; Kara, Sakarya ve Aksu, 2016; Öcal, Atasoy ve Öcal, 2017; Güner ve Kurnaz, 2020), bu iki modeli ve modellerin sunduğu M skorlarını Türkiye'deki şirketleri sınıflandırmak amacıyla kullanmıştır. Diğer taraftan, az sayıda çalışmada (Güler, Emgin ve Uçma, 2013; Tekin, 2017; Uzunoğlu ve Karacaer, 2019) probit regresyon analizi metodolojisi uygulanarak, değişkenlerin kazanç manipülasyonu eylemleri üzerindeki etkisi tespit edilmeye çalışılmıştır. Bu çalışmalarda Beneish'in (1999) veya Küçüksözen'in (2004) modellerindeki değiş̧kenler çoğunlukla korunmuş ve probit regresyon analizi sonucunda yeni modellere ve M skoru katsayılarına ulaşılmıştır.

Güler, Emgin ve Uçma (2013), BİST' te işlem gören şirketlerden oluşturdukları 2008 ve 2009 yılları için iki ayrı şirket-yıl verisi örneklemini, Beneish (1999) modelinde yer alan değişkenler üzerinde değişiklik yapmadan probit regresyon analizi ile incelemişlerdir. Çalışmanın örnekleminde 2008 yılı için 12'si manipülatör olarak sınıflandırılan 68 şirket ve 2009 yılı için 6'sı manipülatör olarak sınıflandırılan 69 şirket yıl verisi yer almıştır. Her iki yıl için yapılan analizler sonucunda elde edilen model katsayıları, orijinal Beneish (1999) modelinden oldukça farklıdır. Analizler sonucunda ulaşılan modellerde 2008 yılı için Satışlardaki Büyüme Endeksi (SGI) ve Kaldıraç Endeksi (LVGI) değişkenleri istatistiksel olarak anlamlıyken 2009 yılı için hiçbir değişken istatistiksel olarak anlamlı bulunamamıştır.

Tekin (2017) çalışmasında 8'i manipülatör olarak sınıflandırılan 73 şirket-yıl verisini Küçüksözen'in (2004) modelinde yer alan değişkenler üzerinde sınırlı bir değişiklik yaparak probit regresyon analizi ile incelemiştir. Bu çalışmada Küçüksözen'in (2004) analiz yaptığ1 dönemde ülkemizdeki yüksek enflasyonu gerekçe göstererek modeline almadığı Satışlardaki Büyüme Endeksi (SGI) değişkeni modele dahil edilirken, Satış ve Genel Yönetim Giderleri Endeksi (PSE) değişkeni modelden çıkarılmıştır. Bu durum, SGI ve PSE değişkenleri arasındaki yüksek korelasyon ve SGI değişkeninin modelde anlamlı bir değişken olması ile açıklanmıştır. Analiz sonuçlarında modelin geliştirildiği özgün çalışmadan oldukça farklı model katsayılarına ulaşılmıştır. Probit regresyon analizi sonucunda Brüt Kar Marjı Endeksi (BKM), Amortisman Endeksi (AME), Finansman Giderlerinin Satışlara Oranı (FSE), Satışlardaki Büyüme Endeksi (SGI) değişkenleri istatistiksel olarak anlamlı bulunmuştur.

Uzunoğlu ve Karacaer (2019) çalışmalarında 12'si manipülatör olarak sınıflandırılan 98 şirket-yıl verisini probit regresyon analizi ile incelemişlerdir. Çalışmada Beneish (1999) modelinde yer alan değişkenlerin yedisi probit modele dahil edilirken Toplam Tahakkukların Toplam Varlıklara Oranı (TATA) modelden çıkarılmıştır. Bu değişken yerine, araştırma ve geliştirme giderleri ile finansman giderleri hesaplarının manipülasyona açık hesaplar olması ve literatürde finansal bilgi manipülasyonunun tespitinde kullanılması gerekçe gösterilerek sürdürülen faaliyetler vergi öncesi kâr tutarını hasılata oranlayan yeni bir değişken (SKHO) kurgulanarak modele eklenmiştir. Bu değişkenle potansiyel bir manipülasyon eylemine işaret etmesi beklenen ölçüm TATA değişkeniyle de ölçülebilecek iken, kapsamı daha sınırlı olan SKHO değişkeni tercih edilmiştir. Çalışma kapsamında yürütülen analizler sonucunda ticari alacaklar endeksi, brüt kâr marjı endeksi, amortisman endeksi, pazarlama satış dağıtım ve genel yönetim giderleri endeksi ve sürdürülen faaliyetler vergi öncesi kârının hasılata oranı değişkenleri anlamlı bulunmuştur. Bu başlık altında değinilen çalışmaların model çıktıları, bulgular başlığında raporlanan analiz çıktılarıyla birlikte sunulmuştur. 


\section{METODOLOJi}

$\mathrm{Bu}$ çalışmada, kazanç manipülasyonlarını tespit etmek için ABD örnekleminde geliştirilen Beneish (1999) modelini Türkiye'deki şirketlerin güncel verisiyle tekrar çalıştırarak, model katsayılarının Türkiye'ye uyarlanması amaçlanmıştır. Böylece, güncellenen katsayılarla modelin Türkiye'de gerçekleştirilen kazanç manipülasyonlarını tespit etme başarımının artması beklenmektedir. Beneish (1999) modelini Türkiye'ye uyarlayan başlıca çalışma Küçüksözen'in (2004) çalışmasıdır. Fakat bu çalışmada Beneish'in orijinal modelindeki bileşenler kısmen değiştirilerek yeni bir model türetilmiştir. Ek olarak, Küçüksözen'in (2004) modelini geliştirdiği döneme ait verilerin bugün Türkiye'nin mevcut ekonomik ve finansal sistemini yansıtmayabileceği düşünülmektedir. Bu sebeple, Beneish'in (1999) orijinal modelinin yanı sıra, Küçüksözen'in (2004) modeli de araştırmaya dâhil edilmiştir. Böylece, Küçüksözen'in (2004) modelini Türk şirketlerinin son dönem verisi üzerine uygulayarak bu model için de güncel katsayılara ulaşılmıştır.

Literatürde, Beneish modelini görece küçük örneklemler üzerinde Türk şirketlerine uygulayan diğer çalışmalar görülmektedir. Beneish ve Küçüksözen'in elde ettiği sonuçların yanı sıra, literatürdeki bu çalışmalarda elde edilen sonuçlar da derlenerek bulgular kısmında karşılaştırmalı olarak sunulmuştur. $\mathrm{Bu}$ sunum, Türkiye'deki kazanç manipülasyonunu açıklayan değişkenlerin etki yönü ve istatistiksel anlamlılık olarak önemini yorumlamayı mümkün k1lmaktadır. Beneish modeli bir probit modeli olup, şirkete ait finansal bilgileri kullanarak şirketi manipülatör olarak sınıflandırmada kullanılacak bir M skoru üretmektedir. Dolayısıyla, raporladığ finansal bilgilerinde gerçekten manipülasyon yaptığı bilinen şirketler ile kontrol şirketlerinin yer aldığ 1 güncel bir örneklemde modelin tespit başarımı ölçülebilmektedir. Çalışmanın bulgular kısmında, modellere ait orijinal katsayılara ve bu çalışmada elde edilen güncel katsayılara sahip modellerin, yakın dönemde yaşanan manipülasyonları saptamadaki başarımları ölçülmüştür.

Probit modelleri, lojistik regresyon modellerinin bir türevi olarak, belirli bir türe dâhil olma veya olayın gerçekleşme olasılığını modellemek ve bunun sonucunda belirli bir yüzdeyle sınıflandırma yapabilmek için kullanılır. Bir probit modeli olan Beneish modelinin bağımlı değişkeni de şirketin t yılında kazanç manipülasyonu gerçekleştirmiş olup olmadığına göre 1 veya 0 değeri alan dikotom değişkendir. Modelin finansal tablo verilerinden oluşturulan bağımsız değişkenlerine ait katsayıları hesaplayabilmek için, bağımlı değişkene ait veriyi oluşturmak gerekmektedir. Bunun için t yılına ait finansal tablo verileri bilinen şirketlerin, t yılında kazanç manipülasyonu yaptığını kesin olarak bilmek gerekir. Literatürde kazanç manipülasyonunun en net ifadesi düzenleyici ve denetleyici otorite tarafindan saptanan finansal bilgi manipülasyonlarıdır. Buna dayanarak, araştırma verisinin oluşturulabilmesi için öncelikle 2013 ile 2019 yılları arasında yayınlanmış olan Sermaye Piyasası Kurumu (SPK) bültenlerinde finansal bilgi manipülasyonuna işaret eden şirket bildirimleri ele alınmıştır.

Benligiray ve Onay (2020), 2013-2019 yıllarını kapsayan dönemde SPK bültenleri içinde muhasebe ve finansal raporlamayı ilgilendiren şirket bildirimlerinde 66 adet şirket saptamışlardır. Bildirimlerde belirtilen ihlallerin ortalama olarak yaklaşık 3 yıl sürdügü gözlenmiştir. İhlalin gerçekleştirilmesi ile saptanması arasında geçen süre yine yaklaşık 3 yıldır. Ek olarak, bildirimlerde bir şirket için birden çok konuya değinildiği gözlenmiştir. Türkiye'de ilgili dönemde SPK tarafından saptanmış finansal bilgi manipülasyonlarının 
niteliği, SPK bildirimlerinin kazanç manipülasyonu için bir vekil olarak kullanılmasıyla elde edilen sonuçların yorumlanmasında kullanılabilir. Nitekim Küçüksözen (2004) Türkiye'de gerçekleşen finansal bilgi manipülasyonlarını sınıflandırarak bir tablo halinde çalışmasında raporlamıştır. $\mathrm{Bu}$ çalışmadaki analizin örnekleminde yer alan manipülatör şirketleri belirlemekte kullanılan 2013-2019 yıllarına ait SPK bültenlerinde yer alan finansal bilgi manipülasyonları için Benligiray ve Onay'ın (2020) oluşturduğu sınıflandırma Tablo 1'de sunulmuştur.

Tablo 1. SPK Bültenlerinde Yer Alan Şirket Bildirimlerindeki İfadelerin Siniflandirılması

\begin{tabular}{lr}
\hline I. Muhasebe ilkeleri, standartlar veya tebliğlere aykırı muhasebe & Adet \\
\hline SPK Finansal Raporlama tebliğine aykırılık (genel ibare) & 20 \\
Yasal defter ve kayıtlarının usulüne uygun tutulmaması & 10 \\
Gerçeğe aykırı kayıt yapılması (stoklar, satışlar, duran varlıklar, alacaklar) & 10 \\
Muhasebe hilesi & 5 \\
Kayıpla sonuçlanması olası durumlar için karşlık ayrılmaması ve & 4 \\
Hile, yanıltıcı belge düzenleme & 3 \\
Varlıkların yeniden değerleme yoluyla olduğundan yüksek gösterilmesi & 2 \\
\hline II. Finansal bilginin iletilmesinde yaşanan diğer aksaklıkların tespiti & Adet \\
\hline Finansal raporların öngörülen süre içerisinde KAP'a gönderilmemesi & 32 \\
Bağımsız denetim raporlarının ve/veya finansal tabloların açılanmaması & 4 \\
İzahname ve halka arz sirkülerindeki taahhütlerin yerine getirilmemesi & 4 \\
\hline III. Şirketi zarara uğratan veya şirket aleyhindeki hukuk dışı & Adet \\
\hline Şirket mal varlığının azaltılması (genel ibare) & 29 \\
Transfer fiyatlamasılla (mal-hizmet, finansal varlık alım-satımı) örtülü aktarım & 14 \\
Alacak için takip yapıllmaması veya alacaktan vazgeçilmesi & 9 \\
İlişkili taraftan alacakların tutarına veya açıklanmasına ilişkin tebliğlere & 7 \\
Şirket varlıklarının çalınması veya zimmete geçirilmesi, şirketin içinin & 6 \\
Şirket varlıklarının suiistimali & 6 \\
\hline
\end{tabular}

2013-2019 döneminde yayınlanan SPK bültenlerinde finansal bilginin iletilmesinde yaşanan aksaklıkları içeren bildirimler, kazanç manipülasyonu ile doğrudan veya dolaylı olarak ilişkisi olmayacağı düşüncesiyle, araştırmanın kapsamı dışında tutulmuştur. Analiz kapsamına alınan şirket bildirimi sayısı 53'tür. Bu kapsamdaki şirketlerin bir kısmı için saptanan ihlal bir yıldan uzun sürmüş ve saptanması bir yıldan fazla zaman almıştır. Bu durumun analizi yanlı veya anlamsız kılmasının önüne geçmek için bildirimlerde manipülasyonun ilk gerçekleştiği $t$ yılı saptanmıştır. Böylece analiz, manipülasyonu tahminlemekte kullanılacak t-1 yilına ait finansal tablo verisini bozacak bir manipülasyon etkisinden arındırılmıştır.

Yukarıda bahsedilen şirketlerden 24 adedi borsa kotundan çıkarılmış ve borsa kotundan çıkarıldıktan sonra 16 adedi iflasını açıklamıştır. Bu şirketler SPK bildiriminde yer aldıktan bir veya iki yıl sonra iflaslarını açıklamışlardır. Buradan yapılacak bir çıkarımla, Türkiye'de SPK bildirimlerine dayanan bir kazanç manipülasyonu tahmin modelinin, şirketlerin iflas olasılığını da belirli bir düzeyde açıklayabileceği düşünülebilir. Müflis veya kottan çıkarılmış şirketlerin finansal tabloları resmi ve özel veri tabanlarından çıkarılmaktadır. 
$\mathrm{Bu}$ sebeple, SPK bildirimiyle belirlenen şirketlerin bir kısmının finansal verisi elde edilememiştir. Analize uygun olarak, manipülasyon yılına ve bir önceki yıla ait tüm verilerine ulaşılabilen manipülatör şirketlerin sayısı 32'dir. Bu şirketlerden biri uç değer oluşturması sebebiyle analiz dışı bırakılmıştır.

Probit modeli için gerekli olan bağımsız değişken değeri sıfır, yani manipülatör olduğu saptanmamış, diğer bir ifadeyle normal kabul edilen şirketler araştırmanın verisini oluşturan diğer şirketlerdir. Bu şirketler aynı zamanda kontrol şirketi olup, hâlihazırdaki modellerin kazanç manipülasyonu tahmin başarımını ölçmek için kullanılmaktadır. Beneish ve benzeri modelleri sınamak için kontrol şirketleri ve manipülatör şirketlerden oluşan her bir şirket-yıl verisi için M skoru hesaplanır. Hesaplanan bu skorlara göre şirketleri sınıflandırmak için bir kesim noktası belirlenir. Böylece, $\mathrm{M}$ skoru kesim noktasının üstünde kalan şirketler manipülatör olarak sınıflandırılmış olur. Probit yönteminde sınıflandırma standart olarak sıfır değerinin altına ve üstüne göre yapılıyor olsa da literatürde sıfırdan farklı kesim noktalarının kullanıldığı görülmektedir. Bu uygulamalarda kesim noktası, modelin manipülatör şirketleri saptama gücünü artıracak şekilde optimize edilmektedir. Benligiray ve Onay (basım aşamasında), farklı modellerin sınıflandırma performansını karşılaştırabilmek amacıyla örneklemdeki gerçek manipülasyon oranını yansıtacak kesim noktaları önermiştir. Beneish modelinin Türkiye'ye uyarlanmış versiyonunu orijinaliyle karşılaştırabilmek için kullanılacak kesim noktalarının belirlenmesinde, araştırmacıların önerdiği bu yaklaşım benimsenmiştir.

Modellerin tahmin gücünün ölçümünde tip I - tip II hata oranları veya bunların bire tamlayanı olan duyarlılık ve özgüllük oranları hesaplanır. Tip I hata, bir şirketin manipülatör olduğu halde manipülatör olmayan bir şirket olarak sinıflandırılması iken, tip II hata manipülatör olmayan bir şirketin manipülatör olarak sınıflandırılmasıdır. Diğer taraftan duyarlılık, manipülatör şirketlerden doğru sınıflandırılanların oranı iken özgüllük, manipülatör olmayan şirketlerin doğru sınıflandırılma oranıdır. Araştırmanın bulgular kısmında modellerin tahmin başarımları tip I-II hata oranları, duyarlılık ve özgüllük oranları bağlamında sunulmuştur. Hem probit modellerine ait değişken katsayılarını hesaplayabilmek hem de bu modellerin tahmin başarımlarını karşılaştırabilmek amacıyla veri setinde kontrol şirketlerinin de yer alması gereklidir. Bu çalışmanın kontrol şirketleri, ele alınan dönem için hakkında manipülasyon bildirimi yapılmamış Borsa İstanbul'a kote şirketlerden finans sektörü, holding yapıları ve spor kulübü şirketleri dışındakilerdir. Bu şirketlerin finansal verileri DataStream veri tabanından elde edilmiştir. ${ }^{3}$ Sonrasında, eldeki veriden rassal olarak 269 şirket-y1l verisi çekilmiş ve böylece yaklaşık yüzde 10'u manipülatör olan 300 birimlik bir örneklem oluşturulmuştur.

\section{BULGULAR}

$\mathrm{Bu}$ başlık altında, metodoloji başlığındaki araştırma tasarımına uygun olarak gerçekleştirilen analizin sonuçları yer almaktadır. Analizde kullanılan veriye ait özelliklerin tanıtılması, sonuçların yorumuna katkı sağlayacaktır. Buna uygun olarak analiz verisi, verinin iki temel boyutu olan şirket ve yıl bazında incelenmiştir. Analiz için oluşturulan veri setindeki manipülatör ve kontrol grubundaki şirketlerin tümü SPKn.'a tabi olmalarına karş1lık, finansal özellikleri bakımından farklılaştıkları görülmüştür. Veri setindeki şirket gruplarının özellikleri Tablo 2'de sunulmuştur. İncelenen dönemde yayımlanan SPK bildirimlerindeki ihlallerin bir

\footnotetext{
${ }^{3} \mathrm{Bu}$ çalışmada kullanılan verilerin veri tabanındaki referans kodları son not olarak sunulmuştur.
} 
kısmının geç saptanması ve süregelen ihlâllerde manipülasyon yılı olarak ilk yılın esas alınması sebebiyle, manipülatör olarak belirlenen şirket-yıl verisinin ele alınan dönemin ilk yıllarında yoğunlaştı̆̆ görülmektedir. Manipülatör şirket-yıl verisinin medyan değeri 2014'tür. Karşılaştırma şirketlerinin finansal verisinde konjonktürel etkiden kaçınmak adına, kontrol şirket-y1l verisinin rassal olarak belirlenmesinde manipülatör şirket-y1l verisiyle y1l olarak medyan değerin aynı olması kriteri uygulanmıştır.

Tablo 2'de sunulan verilerde, iki grup şirket arasında göze çarpan bazı farklılıklar bulunmaktadır. Manipülatör şirketler, diğerlerine göre toplam varlığı daha az, yani daha küçük olan şirketlerdir. Manipülatör şirketlerin net işletme sermayeleri toplam varlıklarına oranla diğer şirketlerden daha azdır. Manipülatör şirketlerde kâr edenlerin oranı görece daha azdır. Bununla birlikte, manipülatör şirketler arasında kâr eden şirketlerin toplam varlıklarına oranla diğer şirketlere göre daha çok kâr ettikleri gözlenmiştir. Manipülatör şirketlerin satışlarındaki ortalama artış oranı, normal şirketlerin ortalama satış oranının iki katından fazladir.

Tablo 2. Veri Setindeki Şirket Gruplarının Finansal Özellikleri

\begin{tabular}{llll}
\hline & Toplam & Manipülatör & Kontrol \\
\hline Şirket-yıl Sayısı & 300 & 31 & 269 \\
Şirket-yıl Yüzdesi & $\% 100$ & $\% 9,68$ & $\% 90,32$ \\
Medyan (t) Yılı & 2014 & 2014 & 2014 \\
Toplam Varlıklar (T.V.) x 1.000* & 2.152 .163 & 642.298 & 2.317 .822 \\
Net İşletme Sermayesi / T.V.* & 0,12 & $-0,09$ & 0,12 \\
Toplam Borç / T.V.* & 0,28 & 0,35 & 0,27 \\
Net Satışlar \% Değişim (t, t-1)* & $\% 21,1$ & $\% 45,5$ & $\% 18,3$ \\
Sürdürülen Faal. Kârı Olanların Yüzdesi & $\% 70,3$ & $\% 51,6$ & $\% 72,5$ \\
Sürdürülen Faal. Kâr/ T.V., (Zarar/T.V.)* & $0,08(0,04)$ & $0,11(0,20)$ & $0,07(0,03)$ \\
& & &
\end{tabular}

*Ortalama değerler

Probit modeliyle katsayıları hesaplanacak iki ayrı modele ait değişkenlerin örneklemdeki şirket-yıl verisinde aldığı değerlerin ortalamaları ve standart sapmaları, manipülatör ve kontrol grupları için Tablo 3 'te sunulmuştur. Beneish (1999) ve Küçüksözen (2004) modellerinde endeks olarak anılan bağımsız değişkenlerin yedi adedi temelde aynıdır. İki ayrı modelin benzerlik gösteren bu değişkenleri Tablo 3'te aynı satırlara denk gelecek şekilde sıralanmıştır. Tabloda, aktifin kalitesini ölçen değişken ikilisi (AQI-AKE) hariç diğer altısının yakın değerler aldığı görülmektedir. Dolayısıyla, bu değişkenlere ait katsayıların yorumlanması da benzer olacaktır.

Tablo 3. Bağımsız Değişkenler için Ortalama ve Standart Sapma Değerleri

\begin{tabular}{rccccrrrrr}
\hline & \multicolumn{1}{c}{ Manipülatör } & \multicolumn{2}{c}{ Kontrol } & \multicolumn{3}{c}{ Manipülatör } & \multicolumn{2}{c}{ Kontrol } \\
\hline Beneish (1999) & $\boldsymbol{\mu}$ & $\boldsymbol{\sigma}$ & $\boldsymbol{\mu}$ & $\boldsymbol{\sigma}$ & Küçüksözen $(2004)$ & $\boldsymbol{\mu}$ & $\boldsymbol{\sigma}$ & $\boldsymbol{\mu}$ & $\boldsymbol{\sigma}$ \\
\hline DSRI & 1,60 & 1,23 & 1,00 & 0,37 & TAE & 1,37 & 1,08 & 1,05 & 0,62 \\
GMI & 0,75 & 0,75 & 1,00 & 0,34 & BKM & 0,75 & 0,75 & 1,00 & 0,34 \\
AQI & 2,70 & 7,36 & 1,07 & 0,57 & AKE & 0,91 & 0,80 & 0,71 & 2,79 \\
SGI & 1,46 & 1,42 & 1,18 & 0,46 & & - & - & - & - \\
DEPI & 1,78 & 2,41 & 1,08 & 0,50 & AME & 1,78 & 2,41 & 1,08 & 0,50 \\
SGAI & 1,09 & 0,52 & 1,01 & 0,30 & PSE & 1,09 & 0,52 & 1,01 & 0,30 \\
LVGI & 1,07 & 0,43 & 1,04 & 0,29 & BYE & 1,46 & 2,12 & 1,16 & 0,84 \\
TATA & $-0,15$ & 0,31 & $-0,02$ & 0,17 & TVE & $-0,15$ & 0,31 & $-0,02$ & 0,17 \\
\hline
\end{tabular}




\begin{tabular}{lllll} 
SSE & 1,15 & 1,31 & 1,06 & 0,45 \\
FSE & 1,90 & 2,80 & 1,34 & 1,72 \\
\hline
\end{tabular}

Probit modeli ile hesaplanmış regresyon parametreleri ile elde edilen denklem doğrusal olup, manipülatör şirketler ve kontrol şirketleri için tahminlenen manipülasyon olasılığını gösteren regresyon eğrisinin y ekseni değerlerine probit dönüşümüyle ulaşılır. Dolayısıyla, Probit model çıtısındaki bağımsız değişken katsayıları büyüklük olarak doğrudan yorumlanamamaktadır. Marjinal etkileri ölçen katsayılar hesaplanmaksızın eldeki katsayılar kullanılarak yapılacak bir yorum, sadece değişken katsayılarının sıfırdan farklılığını gösteren $\mathrm{p}$ değeri ve işaretin yönüdür. Literatürdeki ilgili çalışmalarda sunulan regresyon parametreleri bu iki temel yoruma imkân vermektedir. Dolayısıyla, bu araştırmada geçmiş çalışmaların sonuçlarıyla karşılaştırılabilir olan değişken katsayıları raporlanmıştır. Beneish ve Küçüksözen modellerine göre hesaplanmış iki ayrı probit modeli çıktısı (sırasıyla I. ve II. Probit Modeli), ilgili modelleri baz alan geçmiş çalışmalar ile karşılaştırmalı olarak Tablo 4'te sunulmuştur.

Tablo 4. Probit Model Çıktıları ve Sonuçların Diğer Çalışmalarla Karşılaştırması

\begin{tabular}{|c|c|c|c|c|c|c|c|c|}
\hline & $\begin{array}{c}\text { I. } \\
\text { PROBİT } \\
\text { MODELİ } \\
\text { ÇIKTISI }\end{array}$ & $\begin{array}{l}\text { Beneish } \\
\text { (1999) }\end{array}$ & $\begin{array}{l}\text { Güler, } \\
\text { Emgin, } \\
\text { Uçma } \\
(2013) \\
\end{array}$ & $\begin{array}{l}\text { Uzunoğlu, } \\
\text { Karacaer } \\
(2019)\end{array}$ & & $\begin{array}{c}\text { II. } \\
\text { PROBİT } \\
\text { MODELİ } \\
\text { ÇIKTISI }\end{array}$ & $\begin{array}{l}\text { Küçüksözen } \\
(2004)\end{array}$ & $\begin{array}{l}\text { Tekin } \\
\text { (2017) }\end{array}$ \\
\hline Sabit & $-3,332 *$ & $-4,840 *$ & $-0,023$ & $-7,886$ & Sabit & $-2,555 *$ & $-1,547$ & 10,219 \\
\hline DSRI & $0,950 *$ & $0,920 *$ & $-1,22$ & $1,731 *$ & TAE & $0,350 *$ & $1,276 *$ & 0 \\
\hline GMI & 0,045 & $0,528 *$ & $-0,239$ & $1,883 *$ & BKM & $-0,129$ & $-1,770 *$ & $-2,633 *$ \\
\hline AQI & 0,201 & $0,404 *$ & 0,299 & 0,197 & $\mathrm{AKE}$ & 0,069 & 0,082 & 0,07 \\
\hline SGI & $0,424 *$ & 0,892 & $-2,85 *$ & 1,539 & & - & - & $-3,719 *$ \\
\hline DEPI & $0,247 *$ & 0,115 & 1,118 & $-4,605$ & AME & $0,20 *$ & $0,225 *$ & $-4,312 *$ \\
\hline SGAI & $-0,025$ & $-0,172$ & $-0,457$ & $3,765 *$ & PSE & 0,101 & $-0,488$ & yok \\
\hline LVGI & $-0,317$ & $-0,327$ & $1,55 *$ & 0,755 & BYE & 0,036 & $-0,341$ & 1,247 \\
\hline \multirow[t]{3}{*}{ TATA } & $-2,514 *$ & $4,679 *$ & 0,911 & Farklı değ. & TVE & $-2,03 *$ & $-0,514$ & $-5,347$ \\
\hline & & & & & SSE & 0,059 & 0,972 & $-1,857$ \\
\hline & & & & & FSE & 0,035 & $0,060 *$ & $-0,563 *$ \\
\hline Ki-Kare & 61,19 & 129,20 & 18,07 & 35,16 & & 29,87 & 41,71 & - \\
\hline (p değeri) & $(0,00)$ & $(0,00)$ & $(0,02)$ & $(0,00)$ & & $(0,00)$ & $(0,00)$ & \\
\hline Pseudo R & 0,301 & 0,371 & 0,285 & 0,544 & & 0,149 & 0,318 & 0,492 \\
\hline Örneklem & 300 & 672 & 68 & 98 & & 300 & 126 & 73 \\
\hline (manip/kont) & $(31 / 269)$ & $(24 / 648)$ & $(12 / 56)$ & $(12 / 86)$ & & $(31 / 269)$ & $(27 / 99)$ & $(8 / 65)$ \\
\hline
\end{tabular}

* 0,05 düzeyinde anlamll1ık

31 manipülatör ve 269 kontrol şirket-yıl verisiyle tabloda yer alan I. ve II. Probit Modeli çıktıları, Tablo 4'te yer alan Türkiye örneklemindeki diğer tüm çalışmalardan daha geniş kapsamlıdır. Buna ek olarak, gerçekten manipülasyon olarak nitelendirebilecek resmî bildirimlerin analiz süreci Beneish'in (1999) çalışmasındaki titizlikle yürütülmüş ve detaylı olarak raporlanmıştır. Dolayısıyla, I. Probit Modeli çıktısının, Beneish modelinin Türkiye'deki uygulamasına yönelik net bir tablo çizeceği düşünülebilir. Beneish modelinin Türkiye'deki ilk uygulamasını yapan Küçüksözen (2004), veri setinin oluşturulmasında Beneish (1999) ile aynı özeni gösterip raporlamıştır. Fakat daha önceden de belirtildiği üzere, bu çalışmada kullanılan model, Beneish modelinden farklılıklar göstermektedir. Tablo 4'te sunulan II. Probit Modeli çıktısının, Küçüksözen (2004) Modeli'nin yakın zamana ait güncel veride geçerliliğinin sınanması bakımından net bir görüntü vereceği düşünülmektedir. 
Tablo 4'ün sol tarafında ilk sütunda sunulan I. Probit Modeli çıktısı ile Beneish'in (1999) model çıtısı karşılaştırıldığında, birçok açıdan benzer sonuçlara ulaşıldığ1 görülmektedir. I. Probit Modelinin açıklayıcılık düzeyi Beneish (1999) sonuçlarına yakın olarak \%30 düzeyinde gerçekleşmiştir. Model bir bütün olarak anlamlıdır. Modelde beş bağımsız değişkene ait katsayıların $\alpha=0,05$ düzeyinde anlamlı olduğu görülmektedir. $\mathrm{Bu}$ değişkenler sabit terim, alacaklar endeksi (DSRI), satışlardaki büyüme endeksi (SGI), amortisman endeksi (DEPI) ve toplam tahakkukların toplam varlıklara oranıdır (TATA). I. Probit Modeli çıktısındaki bağımsız değişken katsayıları işaret ve büyüklük olarak diğer çalışmalara kıyasla Beneish (1999) sonuçlarıyla oldukça tutarlıdır. Bunun tek istisnası negatif katsayıya sahip olan tahakkuklar (TATA) değişkenidir. Beneish (1999) pozitif toplam tahakkukların kazanç manipülasyonu olasılığını artırmasını beklemiş ve bulgularıyla desteklemiştir. Türkiye örnekleminde ise, tahakkuklar ile manipülasyon olasılığı arasında ters yönlü ve anlamlı bir ilişki gözlenmiştir.

Tablo 4'ün sağ tarafında ilk sütunda sunulan II. Probit Modeli çıktısı ile Küçüsözen'in (2004) model çıktısı karşılaştırıldığında belirgin farklılıklar gözlenmiştir. Güncel veriyle hesaplanmış II. Probit Modelinin açıklayıcılık düzeyi 2004 öncesi veriyle hesaplanmış Küçüksözen (2004) modeline göre oldukça düşük gerçekleşmiştir. Uygulandığ 1 dönemde Küçüksözen (2004) modeli Beneish (1999) çalışmasına yakın düzeyde açıklayıcılığa sahipken (\%32), günümüzde bu modelin açıklayıcılığının düştüğü (\%15) görülmektedir. Bununla birlikte II. Probit Modeli de bir bütün olarak anlamlıdır. Modelde dört bağımsız değişkene ait katsayıların $\alpha=0,05$ düzeyinde anlamlı olduğu görülmektedir. Bu değişkenler sabit terim, ticari alacaklar endeksi (TAE), amortisman endeksi (AME) ve toplam tahakkukların toplam varlıklara oranıdır (TVE). Küçüksözen'in (2004) orijinal modele ilave ettiği stokların brüt satışlara oranı (SSE) ve finansman giderlerinin brüt satışlara oranı (FSE) bağımsız değişkenleri, güncel veriyle hesaplanmış regresyon analizinde istatistiksel olarak anlamlı bulunmamıştır. Beneish'in orijinal modeli ile karşılaştırıldığında, Türkiye'ye uyarlanmış öncül modelin güncelliği sorgulanabilir.

Tablo 4'ün genel özetinde, Beneish (1999) modelinin Türkiye örneğinde güncelliğini koruduğu; fakat Küçüksözen (2004) modelinin açıklayıcılık olarak zayıfladığı görülmektedir. Beneish'in (1999) ABD verisiyle elde ettiği sonuçları Türkiye'deki sonuçlardan ayıran temel unsur kazanç manipülasyonu ile toplam tahakkuklar arasındaki ilişkidir. I. ve II. Probit Modeli çıktılarıyla paralel olarak, Küçüksözen (2004) de toplam tahakkukların toplam varlıklara oranı değişkeni için negatif katsayıya işaret etmektedir. Buradan hareketle, Türkiye'de toplam tahakkukların yüksek olmasının kazanç manipülasyonu olasılığını azalttığı söylenebilir.

Tablo 3'te raporlandığı üzere, manipülatör şirketlerde toplam tahakkukların ortalama olarak negatif ve kontrol şirketlerine kıyasla daha düşük olduğu dikkate alınırsa, modeldeki tahakkuklar değişkeni katsayısının negatif olmasından yola çıkarak şu söylenebilir: Türkiye'deki şirketler için, toplam tahakkukların düşük (ve hatta negatif) olması, kazanç manipülasyonu olasılığını artırmaktadır. $\mathrm{Bu}$ durum, Tablo 2'de gözlenen, manipülatör şirketlerin çoğunlukla zarar açıkladığı bulgusu ile tutarlıdır. Küçüksözen ve Küçükkocaoğlu (2004: 45) bu bulguyu tahakkukların gelir azaltıcı yönde kullanıldığına da yorulabileceğini belirtmişlerdir. Aynı çalışmada Türkiye'de gözlenen dönem karını azaltıcı finansal bilgi manipülasyonu tekniklerine de yer verilmiştir (Küçüksözen ve Küçükkocaoğlu: 36). Bunlar, 
Tablo 1'de "şirketi zarara uğratan uygulamalar ve şirket aleyhindeki hukuk dişı uygulamalar" olarak tanımlanan eylemler olup, güncel SPK bildirimlerinde de sıkça gözlenmiştir.

Probit modeli çıktısından elde edilen parametrelerle hesaplanan şirket-y1l verisinin $\mathrm{x}$ ekseninde yer alan $\mathrm{M}$ skorlarına $\mathrm{Z}$ dönüşümü uygulandığında elde edilen değerleri y ekseninde gösteren Probit regresyon eğrisi Şekil 1'de sunulmuştur. Şekilde, regresyon eğrisine ilaveten, her bir şirket-yıl verisi için manipülatör olup olmadığına göre y değeri bir veya sıfır olan örneklem birimlerine de yer verilmiştir. Buradaki probit modelinde, geleneksel olarak sıfır kesim noktasına göre yapılacak bir sınıflandırmanın başarılı olmayacağı şekilden görülebilir. Kesim noktasını farklı bir kriterle belirlemek sınıflandırma başarımını arttırabilmektedir. Nitekim, Beneish (1999) modeli için negatif bir kesim noktası önermiştir. I. Probit Modeli için, kesim noktası -0,95 olarak belirlendiğinde elde edilecek sınıflandırma Şekil 1'de görülebilmektedir.

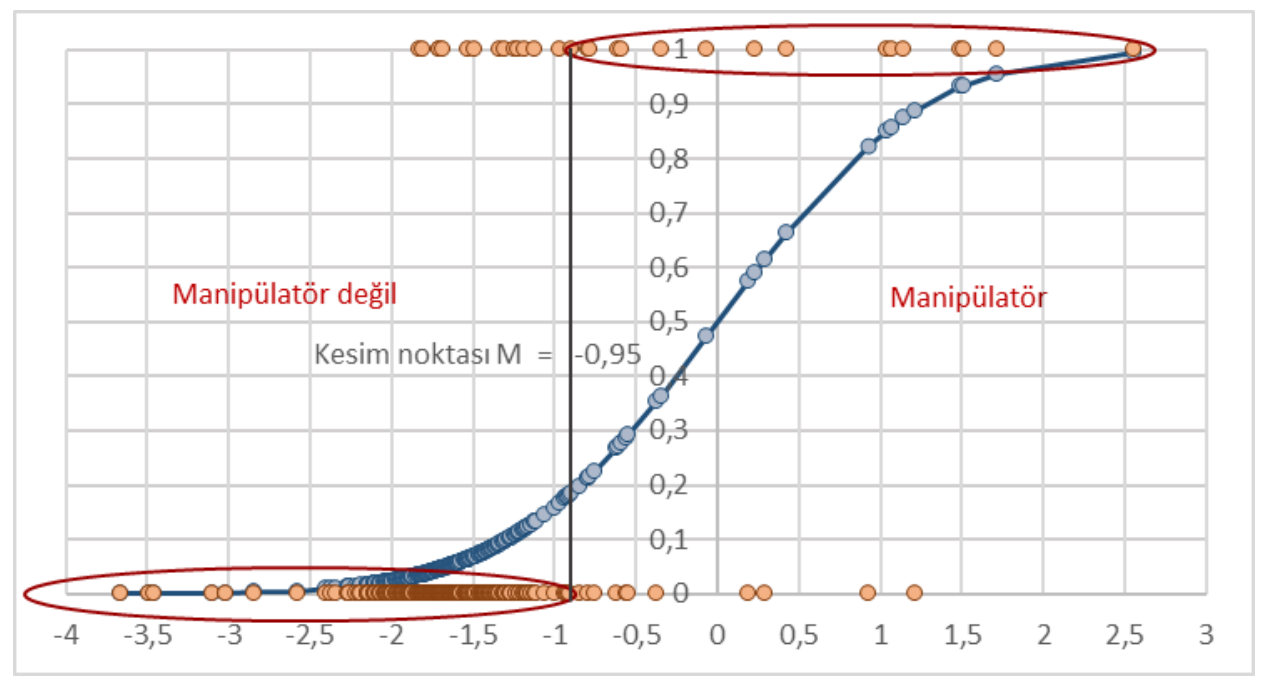

Şekil 1. I. Probit Modeliyle Şirketlerin Sınıflandırılması ve Kesim Noktasının Gösterimi

Beneish (1999), modeliyle yapılacak bir sınıflandırmada tip I hatadan doğacak maliyetlerin tip II hataya göre daha yüksek olacağını belirtmiş ve bu sebeple tip I hatayı düşürürken, tip II hatayı katlanılabilir bir seviyede tutacak bir kesim noktası belirlemiştir. Buna göre, çalışmadaki orijinal ABD verisinde, M skoru -1,78'den büyük olan şirketler manipülatör olarak sınıflandırıldığında tip I hata $\% 45,68$, tip II hata $\% 9,13$ düzeyinde gerçekleşmiştir. Ayrıca bu kesim noktasıyla tahmin edilen manipülatör yüzdesi, örneklemdeki gerçek manipülatör yüzdesiyle uyuşmaktadır. Dolayısıyla, I. Probit Modeline ait katsayılarla elde edilen M skorlarının sınıflandırılmasında belirlenecek kesim noktası benzer özellikleri karşılamalıdır. I. Probit Modeli için M skoru kesim noktası olarak -0,95 belirlendiğinde tahmin edilen manipülatör şirket oranı $(\% 10,33)$, örneklemde manipülatör olduğu bilinen şirket oranına $(\% 10,33)$ eşit olmaktadır. Böylece, Beneish modelinin örneklemdeki güncel manipülasyonları saptamada kullanılacak değişken katsayıları formülünü veren I. Probit Modeli için M skoru kesim noktası -0,95 olarak belirlenmiştir.

Beneish (1999) modelinde belirlenen katsayılar korunarak, orijinal Beneish modeliyle de bir sınıflandırmaya gidilebilir. Beneish modeliyle $M$ skoru hesaplamak için gerekli 
değişken katsayıları literatür kısmında verilmiştir. Bu katsayılar ile elde edilen M skorları için Türkiye örneklemine uygun kesim noktası -1,48 olarak belirlenmiştir. Orijinal Beneish modeli katsayıları için M skoru kesim noktası olarak -1,48 belirlendiğinde tahmin edilen manipülatör şirket oranı $(\% 10,33)$, örneklemde manipülatör olduğu bilinen şirket oranına $(\% 10,33)$ eşit olmaktadır. Bu kesim noktaları uyarınca, Türkiye örneklemi için özel olarak geliştirilen katsayılara sahip I. Probit Modeli ile orijinal katsayılarıyla Beneish modelinin Türkiye'deki manipülasyonları tahminleme başarımları karşılaştırmalı olarak Tablo 5'de sunulmuştur.

Tablo 5. Veri Setindeki Şirketlerin Farklı Modeller Sınıflandırılması

\begin{tabular}{|c|c|c|c|c|c|c|}
\hline \multirow{2}{*}{$\begin{array}{l}\text { Tahmin } \\
\text { Modeli }\end{array}$} & \multirow{2}{*}{$\begin{array}{c}\text { Kesim } \\
\text { Noktas1 }\end{array}$} & \multicolumn{2}{|c|}{ Tahmin Hatası Yüzdesi } & \multicolumn{2}{|c|}{ Tahmin Başarı Yüzdesi } & \multirow{2}{*}{$\begin{array}{c}\text { Tahmin Edilen } \\
\text { Manipülatör Oranı } \\
(\text { Gerçek=\%10,33) }\end{array}$} \\
\hline & & Tip I & Tip II & Duyarlılık & Özgüllük & \\
\hline $\begin{array}{l}\text { I. Probit } \\
\text { Modeli }\end{array}$ & $-0,95$ & 45,16 & 5,98 & 54,84 & 94,42 & 10,33 \\
\hline $\begin{array}{l}\text { Beneish } \\
\text { (Orijinal) }\end{array}$ & $-1,48$ & 54,84 & 6,32 & 45,16 & 93,68 & 10,33 \\
\hline
\end{tabular}

$\mathrm{Bu}$ çalışmada geliştirilen I. Probit Modelinin 2013-2019 döneminde gerçekleşen manipülasyonları tespit yeteneğinin orijinal Beneish modeline göre daha yüksek olduğu Tablo 5 'te görülmektedir. Benzer hesaplamalar II. Probit Modeli için de yapılmış, fakat gösterdiği zayıf performanstan ötürü raporlanmamıştır. Sonuç olarak, Beneish (1999) çalışmasıyla eşdeğer performansa sahip I. Probit Modeli'nin aşağıda sunulan formülü $M=-0,95$ kesim noktası ile Türkiye özelindeki güncel kazanç manipülasyonlarını tespit etmek için kullanılabilir:

$$
\begin{aligned}
M_{i}=-3,332 & +0,950 \times D S R I+0,045 \times G M I+0,201 \times A Q I+0,424 \times S G I+0,247 \\
& \times D E P I
\end{aligned}
$$$$
-0,025 \times S G A I-0,317 \times L V G I-2,514 \times \text { TATA }
$$

\section{SONUÇ}

Kazanç manipülasyonlarını tespit etmek amacıyla ABD şirketlerinin verisiyle geliştirilen Beneish (1999) modeli ve bu modelin Türkiye özelinde geliştirilen bir türevi olan Küçüksözen (2004) modeli manipülatör şirketleri inceleyen çalışmalarda bir sınıflandırma aracı olarak sıkça kullanılmaktadır. Bu modellerden ilki, farklı bir ekonomik/yasal çevreyi baz alması nedeniyle, ikincisi ise Türkiye'de sermaye piyasalarının gelişme kaydettiği dönemin öncesine ait olması sebebiyle Türkiye'nin güncel koşullarındaki uygulanabilirliklerine dair soru işaretleri taşımaktadır. Bu çalışmada, bahsedilen modellerin Türkiye'deki şirketlere ait güncel veri üzerinde tekrar türetilmesi ve güncel model katsayılarıyla Türkiye'de yakın dönem kazanç manipülasyonlarını tahmin etmedeki başarımlarının sınanması amaçlanmıştır.

Kazanç manipülasyonu tespit modellerini çalıştırabilmek için, ilk aşamada, manipülatör şirketlerin yer aldığ 1 geniş boyutta bir örneklem oluşturulmuştur. Manipülatör şirketleri belirlemek için 2013-2019 yılları arasında yayınlanan SPK bültenleri içinde muhasebe ve finansal raporlamayı ilgilendiren şirket bildirimlerinde muhasebe ve finansal raporlamayı düzenleyen tebliğlere aykırılık oluşturan ve suç duyurusu, idari para cezası, 
yaptırım ve tedbirlere konu olan uygulamalar incelenmiştir. Bu uygulamalar çeşitlilik göstermelerine karşın, üç temel gruba ayrılarak raporlanmıştır. Bu gruplardan "muhasebe ilkeleri, standartlar veya tebliğlere aykırı muhasebe uygulamaları" ile "şirketi zarara uğratan veya şirket aleyhindeki hukuk dişı uygulamalar"a yönelik düzenleyici ve denetleyici otoritenin tespitlerine dayanarak örneklemin manipülatör şirketleri belirlenmiştir.

Kazanç manipülasyonu tespit modeli temelde bir probit modelidir. $\mathrm{Bu}$ modelde şirketin manipülatör olup olmadığına göre bir veya sıfır değeri alan dikotom bağımlı değişkene karşılık şirketin finansal verilerinden oluşan bağımsız değişkenler yer alır. Türetilen veri seti ile probit modelleri hesaplandığında Beneish modelinin açıklayıcılık düzeyi, modelin ve bağımsız değişkenlerin istatistiksel anlamlılığı, değişken katsayılarının işareti ve büyüklüğü açısından Türkiye'deki güncel veriye uyduğu görülmüştür. Küçüksözen'in geliştirdiği modele yönelik yapılan analizlerde ise aynı yorum yapılamamaktadır.

Her iki modele ait regresyon çıktısında da toplam tahakkukların toplam varlıklara oranı değişkenine ait katsayı negatif ve istatistiksel olarak anlamlıdır. Bu durum orijinal modelin öngörülerine ters olan tek bulgudur. Bu sonuca göre, Türkiye'deki şirketler için toplam tahakkukların düşük (ve hatta negatif) olması, kazanç manipülasyonu olasılığını artırmaktadır. Buradaki aykırılık, şirketi zarara uğratan uygulamalar ve şirket aleyhindeki hukuk dışı uygulamaların kazanç manipülasyonu olarak kabul edilmesinden kaynaklanıyor olabilir. Bu gruptaki uygulamaların, kazancı artırıcı yönde tahakkukları yükseltmektense, azaltıcı etki yapıyor olması muhtemeldir. SPK bültenlerinde bildirilen manipülatif eylem gruplarına göre model çıktılarını kesitsel olarak analiz eden bir çalışma bu ihtimali netleştirerek literatüre katkı sağlayabilir.

Literatürde, Türkiye'deki kazanç manipülasyonlarının tespiti için Beneish modelinin ABD şirketlerini baz alarak geliştirdiği model katsayılarının ve bu model özelinde belirlenen kesim noktasının kullanıldığı görülmektedir. Türkiye'deki manipülatör şirketlerin saptanmasında kullanılacak endekslerin ağırlıkları yabancı bir ülkedeki şirketlerin geçmişte bir döneme ait verisiyle türetilmiş endeks ağırlıklardan farklılık gösterebilir. Eğer böyle ise, bu durum orijinal modelin Türkiye'deki sınıflandırma başarımını düşürecektir. Buradan hareketle, Türk şirketlerine ait güncel veriyle modele ait katsayılar türetilmiş ve bu katsayıları baz alarak manipülatör şirketler sınıflandırılmıştır. Orijinal model ile kıyaslandığında, bu çalışmada türetilen probit modelinin Türkiye'deki manipülatör şirketlerin tespitinde daha başarılı olduğu görülmüştür. Türkiye özelinde kazanç manipülasyonlarını tespit etmek için Beneish modelini kullanan araştırmacıların bu çalışmada raporlanan parametreleri ve kesim noktasını kullanması önerilmektedir.

\section{NOTLAR}

Çalışmada kullanılan finansal verilerin Datastream veri tabanındaki Worldscope referans kodları aşağıda sunulmuştur:

Hazır Değerler WC02005; Alacaklar WC02051; Ticari Alacaklar WC18297; Stoklar WC02101; Dönen Varlıklar WC02201; Maddi Duran Varlıklar WC02501; Toplam Varlıklar WC02999; Kısa Vadeli Borçlar ve Uzun Vadeli Borçların Kısa Vadeli Kısmı WC03051; Uzun Vadeli Borçların Kısa Vadeli Kısmı WC18232; Kısa Vadeli Borçlar WC03051 - 
WC18232; Kısa Vadeli Yükümlülükler WC03101; Ödenecek Vergiler WC03063; Uzun Vadeli Borçlar WC03251; Net Satışlar WC01001; Satılan Malın Maliyeti WC01051; Amortisman Giderleri WC02401; Faaliyet Giderleri WC01101; Araştırma ve Geliştirme Giderleri WC01201; Satış ve Genel Yönetim Giderleri WC01101 -WC01201; Finansman (Faiz) Giderleri WC01251; Sürdürülen Faaliyetlerden Kâr/Zarar WC01551.

\section{KAYNAKLAR}

Akra, R. M.- Chaya, J. K. (2020), “Testing the Effectiveness of Altman and Beneish Models in Detecting Financial Fraud and Financial Manipulation: Case Study Kuwaiti Stock Market", International Journal of Business and Management, 15(10), pp.70-81.

Bekçi, İ.- Avşarlıgil, N. (2011), "Finansal Bilgi Manipülasyonu Yöntemlerinden Yaratıcı Muhasebe ve Bir Uygulama”, Muhasebe Bilim Dünyası Dergisi, 13(2), ss.131-162.

Beneish, M. D. (1999), “The Detection of Earnings Manipulation”, Financial Analysts Journal, 55(5), pp.24-36.

Beneish, M. D.- Lee, C. M.- Nichols, D. C. (2013), "Earnings Manipulation and Expected Returns", Financial Analysts Journal, 69(2), pp.57-82.

Benligiray, S.- Onay, A. (2020), "Finansal Bilgi Manipülasyonu Bağlamında Bağımsız Denetçi Raporlarının ve SPK Bültenlerinin İncelenmesi", Anadolu Üniversitesi İşletme Fakültesi Dergisi, 2 (2), ss.13-43.

Comporek, M. (2020), "The effectiveness of the Beneish model in the detection of accounting violations-the example of companies sanctioned by the Polish Financial Supervision Authority", Research Papers of Wroclaw University of Economics and Business, 64(10), pp.18-30.

Güler, S.- Emgin, O.- Uçma, T. (2013), “A Pragmatic Manifest for Ethics in Emerging Markets: The Prediction of Manipulation in Turkey By Using Beneish's Model" World of Accounting Science Journal, 15(3), pp.149-165.

Güner, M.- Kurnaz, E. (2020), "Muhasebe Manipülasyonunun Beneish Modeli Yardımıyla Ölçülmesi: BIST Kimya, Petrol, Plastik Endeksi Şirketleri Üzerine Bir Araştırma", Muhasebe ve Vergi Uygulamaları Dergisi, 13(2), ss.195-214.

Hołda, A. (2020), "Using the Beneish M-score model: Evidence from non-financial companies listed on the Warsaw Stock Exchange", Investment Management \& Financial Innovations, 17(4), pp.389-401.

Jolly, T.- Chandani, A. (2020), "Earnings Manipulation in Listed Automobile Companies Using Beneish M-Score and Altman Z-Score Model”, International Journal of Modern Agriculture, 9(3), pp.1327-1347.

Kara, S.- Sakarya, Ş.- Aksu, M. (2016), "Beneish Modeli İle Kazanç Manipülasyonunun Tespit Edilmesi: BIST Şirketleri Üzerine Ampirik Bir Uygulama”, Alanya İşletme Fakültesi Dergisi, 8(2), ss.13-25. 
Kukreja, G.- Gupta, S. M.- Sarea, A. M.- Kumaraswamy, S. (2020), "Beneish M-score and Altman Z-score as a catalyst for corporate fraud detection" Journal of Investment Compliance, 21(4), pp.231-242.

Küçüksözen, C. (2004), "Finansal Bilgi Manipülasyonu: Nedenleri, Yöntemleri, Amaçları, Teknikleri, Sonuçları ve İMKB Şirketleri Üzerine Ampirik Bir Çalışma (Doktora Tezi)", Ankara Üniversitesi, Ankara.

Küçüksözen, C.- Küçükkocaoğlu, G. (2004), "Finansal Bilgi Manipülasyonu: İMKB Şirketleri Üzerine Ampirik Bir Çalışma", 1st International Accounting Conference on the Way to Convergence, MÖDAV, İstanbul.

Onay, A.- Benligiray, S. (2021), "Denetim Raporlarına Göre Kazancını Yöneten Şirketlerde Toplam ve Spesifik Tahakkuklar Üzerine Bir Araştırma”, Uluslararası Sosyal Bilimler ve Eğitim Bilimleri Sempozyumu, USVES.

Öcal, N.- Atasoy, Y.- Ö. Öcal (2017), "Muhasebe Bazlı Kazanç Manipülasyonunun Tespitinde Kullanılan Beneish Modelinin Test Edilmesi”, 21. Finans Sempozyumu, Balıkesir.

Svabova, L. (2021), "Detecting the manipulation of earnings in the company: triangulation of methods", In SHS Web of Conferences (Vol. 92). EDP Sciences. Globalization and its Socio-Economic Consequences.

Svabova. L.- Kramarova, K.- Chutka, J.- Strakova, L. (2020), "Detecting earnings manipulation and fraudulent financial reporting in Slovakia", Oeconomia Copernicana, 11(3), pp.485-508.

Tekin, E. (2017), “2010-2014 Yılları Arasında Türkiye'de Halka Açık Şirketlerde Manipülasyon Üzerine Beneish Modeli İle Ampirik Çalışma (Yayınlanmamış Doktora Tezi)", Başkent Üniversitesi, Ankara.

Uzunoğlu, H.- Karacaer, S. (2019), "Finansal Bilgi Manipülasyonu: BIST Sınai Endeksi Üzerine Bir Çalışma", Hacettepe Üniversitesi İktisadi ve İdari Bilimler Fakültesi Dergisi, 37(3), ss.547-564.

Valaskova, K.- Fedorko, R. (2021), "Beneish M-score: A measure of fraudulent financial transactions in global environment?", In SHS Web of Conferences (Vol. 92). EDP Sciences. Globalization and its Socio-Economic Consequences, pp.1-11.

Varıcı, İ.- Er, B. (2013), "Muhasebe Manipülasyonu ve Firma Performansı ilişkisi: İMKB Uygulaması”, Ege Akademik Bakış Dergisi, 13(1), ss.43-52.

Vetoshkina, E.- Cherepanova, P.- Semenikhina, N.- Tukhvatullin, R. (2020), "Financial Statements Fraud Detection: Analysis of Beneish and Roxas Models Applicability (Russian Approach)", Helix, 10(5), pp.212-217. 